\title{
Three-year experience in the Emergency Department: the approach to patients with spinal trauma and their prognosis
}

\author{
Hızır Ufuk Akdemir, M.D., ${ }^{1}$ Dursun Aygün, M.D., ${ }^{2}$ Celal Katı, M.D., ${ }^{1}$ \\ Mehmet Altuntaş, M.D., ${ }^{1}$ Cengiz Çokluk, M.D. ${ }^{3}$
}

1Department of Emergency Medicine, Ondokuz Mayıs University Faculty of Medicine, Samsun

${ }^{2}$ Department of Neurology, Ondokuz Mayıs University Faculty of Medicine, Samsun

${ }^{3}$ Department of Neurosurgery, Ondokuz Mayıs University Faculty of Medicine, Samsun

\begin{abstract}
BACKGROUND: Spinal cord injuries result in critical pecuniary and/or non-pecuniary losses due to the developing neurological problems. The objective of this study was to evaluate spinal injuries in terms of clinical severity and prognosis. Spinal injuries lead to serious clinical results due to the high rates of morbidity and mortality; however, there is a lack of reliable information on spinal injuries in our country.
\end{abstract}

METHODS: Following the approval of the Faculty Ethics Committee, this retrospective study was conducted on 91 patients aged $\geq 18$ (59 male, 32 female) with spinal trauma who were admitted to the Emergency Department of Ondokuz Mayis University over three years. The patients were assessed in terms of demographics, clinical severity, developing complications, and mortality.

RESULTS: Forty-three patients had complete injuries, while 48 had incomplete injuries. Forty-six patients suffered spinal injuries due to fall from height, 35 patients due to traffic accidents, and 10 patients due to other reasons. Several complications were observed in 52 patients, while no complication occurred in 39 patients. We determined that 19 of 92 patients involved in this study died, while 72 were discharged from the hospital.

CONCLUSION: Spinal cord injuries generally result in unfavorable clinical results. Therefore, an appropriate approach (early diagnosis and true treatment) in emergency services has great significance.

Key words: Clinical severity, complication, prognosis, spinal trauma.

\section{INTRODUCTION}

A spinal cord injury is one of the uncommon Emergency Department admissions. Studies on the frequency of spinal cord injuries in Emergency Departments are highly rare in the literature. Spinal cord injuries and subsequent neurological problems affect a person's social life and result in serious pecuniary and/or non-pecuniary losses. ${ }^{[1]}$ Acute spinal cord injuries are

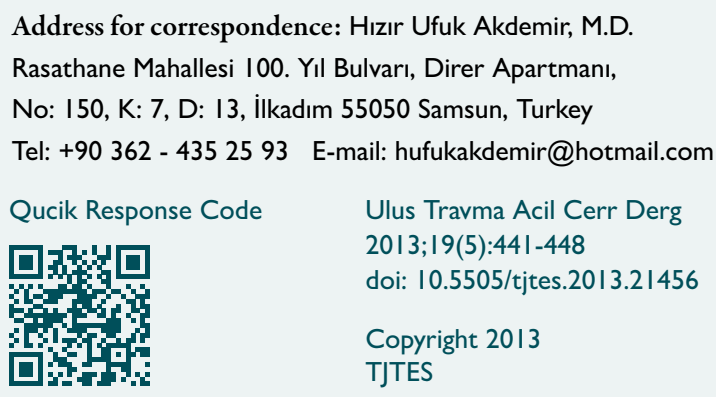

reported to occur at a rate of $20-40 / 1.000 .000 .{ }^{[2]}$ It is reported that spinal cord injuries occur more frequently in young persons, with a male/female ratio of $4 / I$, and that the most common cause of spinal cord injuries is motor vehicle accidents, at a rate of $40 \% .{ }^{[2]}$ Spinal cord injuries are classified as complete (ASIA-A) or incomplete (ASIA-B, C, D) by the American Spinal Injury Association (ASIA).$^{[3,4]}$ By the means of this classification, neurological recovery or deterioration that may occur during the patient follow-up is assessed more clearly.

Approximately half of the patients with spinal cord injuries have complete transection. Currently, there remains no effective medical treatment to restore neurological function in patients with complete spinal cord injuries, except for methylprednisolone. ${ }^{[5]}$ Methylprednisolone is suggested to be beneficial because it is a radical scavenger, prevents lipid peroxidation and has neuroprotective effects. ${ }^{[6]}$ The incidence of complete spinal cord injuries has decreased depending on such actions as timely and properly rendered first aid, more 
favorable resuscitation, and the fastening of seat belts. All these factors positively influence the recovery process. ${ }^{[7]}$

Epidemiological information on spinal traumas is generally obtained from the international literature because there is no reliable information on the incidence of spinal cord injuries in our country. In this study, we retrospectively assessed the demographics of the spinal trauma patients admitted to our Emergency Department, lesion locations, type of neurological impairment, clinical severity according to the results of ASIA assessment during first admission and discharge, treatment efficacy, complications, and the mortality rate.

\section{MATERIALS AND METHODS}

Following the approval of the Faculty Ethics Committee, 91 patients with spinal trauma older than 18 years who were admitted to our Emergency Department over three years were included in the study.

Exclusion criteria were: a) spinal cord impairment with a nontraumatic cause, and b) initiation of treatments at another center. The patients were divided into two groups as those with complete injuries (Grade A/Group I) and those with incomplete injuries (Grades B, C, D/Group 2) according to the clinical findings during admission based on ASIA-International Medical Society of Paraplegia (IMSOP) Impairment Scale (Table I).

The patients were divided into three subgroups as $<45$ years of age, 45-65 years of age and $>65$ years of age. Data on the complete injury group and the incomplete injury group were compared. The patients were divided into two groups based on their admission time to the Emergency Department after the spinal trauma. The first group consisted of the patients admitted to the Emergency Department within the first eight hours following spinal trauma, while the second group includ- ed the patients admitted to the Emergency Department after more than eight hours.

Routine physical and neurological examination of the patients was performed by the emergency physicians. For each patient, vital signs were obtained, muscle strength (Medical Research Council (MRC) score 0 to 5 scale) and spinal reflexes were tested, and sensory examination was performed. Following these assessments, each patient was graded on ASIAIMSOP Impairment Scale, and thus their injuries were defined as complete or incomplete.

Computed radiography (CR) images of the spinal cord, direct radiography (DR) images and magnetic resonance imagings (MRI) were obtained.

The patients with complete and incomplete injuries were divided into two groups as those who received steroid treatment and those who did not. The patients were also divided into groups according to the type of the treatment (medical and/or surgical). The patients with complete and incomplete injuries were compared regarding the treatment, developing complications and mortality.

Predischarge neurological findings of the patients in the complete (ASIA-IMSOP Grade A/Group I) and incomplete (ASIA-IMSOP Grades B, C, D/Group 2) injury groups were obtained from their file information. By means of this information, final ASIA-IMSOP Impairment Scale grades of the patients were determined, and the patients were reassessed in terms of recovery and deterioration in locomotor functions. Intergroup or intragroup changes were defined by the ASIAIMSOP Impairment Scale.

All data of the patients were recorded in pre-prepared study forms and analyzed using the Statistical Package for the Social Sciences (SPSS) 20 software. The relationship between the

Table I. ASIA-IMSOP Impairment Scale ${ }^{[3]}$

\begin{tabular}{lll}
\hline Grade & Injury Type & Neurological Assessment \\
\hline $\begin{array}{ll}\text { Grade A } \\
\text { Grade B }\end{array}$ & $\begin{array}{l}\text { Complete } \\
\text { Incomplete }\end{array}$ & $\begin{array}{l}\text { No motor or sensory function is preserved in the sacral segments S4-S5. } \\
\text { Sensory but not motor function is preserved below the neurological } \\
\text { level zand the injury includes the sacral segments S4-S5. }\end{array}$ \\
Grade C & Incomplete & $\begin{array}{l}\text { Motor function is preserved below the neurological level and more than } \\
\text { half of key muscles below the neurological level have a muscle grade of } \\
\text { less than } 3 .\end{array}$ \\
Grade D & Incomplete & $\begin{array}{l}\text { Motor function is preserved below the neurological level and at least } \\
\text { half of the key muscles below the neurological level have a muscle grade } \\
\text { of } 3 \text { or more. }\end{array}$ \\
Grade E & Normal motor and sensory function
\end{tabular}

ASIA-IMSOP: American Spinal Injury Association-International Medical Society of Paraplegia. 
types of injury (complete and incomplete) and demographic characteristics was analyzed using chi-square test. Lesion sites, accompanying traumas, developing complications, and mortality rates were analyzed using two-proportion $z$ test. The level of statistical significance was accepted as $p<0.05$.

\section{RESULTS}

In three years, 36.430 patients, 91 of whom had spinal trauma, were admitted to our Emergency Department. We calculated the frequency of spinal cord injuries in all emergency admissions each year as $0.25 \%$, and the frequency of spinal cord injuries in trauma patients as $2 \%$. In our study, the frequency of vertebral column injuries in all emergency admissions each year was $7 \%$, and the frequency of vertebral column injuries in trauma patients was $5.6 \%$. Forty-three (47\%) of the 91 patients with spinal trauma had complete injuries, while 48 (53\%) had incomplete injuries.

Fifty-nine $(65 \%)$ of the 91 patients with spinal trauma were male, while 32 (35\%) were female. The numbers of male patients were higher in both the complete and incomplete injury groups. No statistically significant difference was found for gender between the two groups $(p>0.05)$. In our study, the male/female ratio was $1.8 / \mathrm{I}$.

Forty-three patients (47\%) were under 45 years of age, 37 patients ( 4 I \%) were $45-65$ years of age, and II patients (I $2 \%$ ) were over 65 years of age. No statistically significant differ- ence was found for age between the patients with complete and incomplete injuries $(p>0.05)$.

Forty-six patients (50.5\%) were exposed to spinal trauma by fall from height, 35 patients (38.5\%) in traffic accidents, and 10 patients (11\%) due to other reasons (diving into water, being struck by a falling object). A comparison of the patients with complete and incomplete injuries for trauma mechanisms did not reach statistical significance $(p>0.05)$.

Twenty patients $(22.0 \%)$ suffered spinal trauma in the spring, $34(37.4 \%)$ in the summer, $27(29.7 \%)$ in the autumn, and 10 (11.0\%) in the winter. As seen, most emergency admissions were in the summer, followed by autumn, spring and winter, respectively.

The complaints of 43 patients with complete spinal injuries were pain (36 patients, $86 \%$ ), numbness-tingling (38 patients, $88 \%$ ), and loss of muscle strength (100\%). The complaints of 48 patients with incomplete spinal injuries were pain (43 patients, 90\%), numbness-tingling (44 patients, 92\%) and muscle weakness (40 patients, $83 \%$ ). Comparison of the complaints of the patients with complete and incomplete injuries during emergency visits did not reach statistical significance $(p>0.05)$. Table 2 shows the demographic data of the patients with complete and incomplete spinal injuries.

The patients diagnosed with spinal trauma were divided into two groups as those with complete injuries (Group I) and

Table 2. Demographic data on the patients with complete and incomplete injuries

\begin{tabular}{|c|c|c|c|c|c|c|}
\hline & \multicolumn{2}{|c|}{ Complete $(n=43)$} & \multicolumn{2}{|c|}{ Incomplete $(n=48)$} & \multirow[t]{2}{*}{$\mathbf{n}$} & \multirow[t]{2}{*}{$\mathbf{p}$} \\
\hline & $\mathbf{n}$ & $\%$ & $\mathbf{n}$ & $\%$ & & \\
\hline \multicolumn{7}{|l|}{ Sex } \\
\hline Female & 14 & 32.6 & 18 & 37.5 & 32 & $p>0.05$ \\
\hline Male & 29 & 67.4 & 30 & 62.5 & 59 & \\
\hline \multicolumn{7}{|l|}{ Age group } \\
\hline Under 45 years of age & 18 & 51.2 & 25 & 50.0 & 43 & \\
\hline $45-65$ years of age & 18 & 39.5 & 19 & 37.5 & 37 & $p>0.05$ \\
\hline Over 65 years of age & 7 & 9.3 & 4 & 12.5 & II & \\
\hline \multicolumn{7}{|l|}{ Cause of trauma } \\
\hline Fall from height & 22 & 51.2 & 24 & 50.0 & 46 & \\
\hline Traffic accident & 17 & 39.5 & 18 & 37.5 & 35 & $p>0.05$ \\
\hline Other & 4 & 9.3 & 6 & 12.5 & 10 & \\
\hline \multicolumn{7}{|l|}{ Season } \\
\hline Spring & 7 & 16.3 & 13 & 27.1 & 20 & \\
\hline Summer & 14 & 32.6 & 20 & 41.7 & 34 & $p>0.05$ \\
\hline Autumn & 18 & 41.9 & 9 & 18.8 & 27 & \\
\hline Winter & 4 & 9.3 & 6 & 12.5 & 10 & \\
\hline
\end{tabular}

$\mathrm{p}<0.05$ significance level. 
those with incomplete (Group 2) injuries according to their ASIA-IMSOP Impairment Scale grades during admission. All of the complete injuries ( $n=43,100 \%)$ were classified as $A$ according to the ASIA Impairment Scale. Twenty-seven (56\%) of the incomplete injuries were classified as C, while 2 I (44\%) were classified as $D$.

Locomotor functions were restored in 3 (7.5\%) of 43 patients (ASIA A) in the complete injury group according to the clinical assessment during admission. Two (4\%) of 48 patients $(27$ ASIA C, 2I ASIA D) in the incomplete injury group according to the clinical assessment during admission were classified as A, 3 patients $(6 \%)$ as E, 18 patients (38\%) as C, and 25 patients (52\%) as D. Two of 27 patients in the incomplete injury group according to the clinical assessment during admission and classified as AISA $C$ suffered deterioration to ASIA A, while 7 of them recovered to ASIA D. Three of 21 patients in the incomplete injury group according to the clinical assessment during admission and classified as ASIA D recovered to ASIA E. Locomotor functions were restored in 10 of 48 (27 ASIA C, 2I ASIA D) patients in the incomplete injury group according to the clinical assessment during admission. Comparison of the patients with complete and incomplete injuries by recovery status was close to reaching statistical significance in favor of the incomplete injury group $(p<0.05)$. Thirty-nine (9l\%) of the patients with complete injuries suf- fered paraplegia, and 4 (9\%) suffered quadriplegia. Nineteen (39\%) of the patients with incomplete injuries suffered paraparesis, I 8 (38\%) suffered quadriparesis, and II (23\%) suffered hemiparesis.

Table 3 shows the distribution of patients with complete and incomplete spinal injuries by lesion sites.

Twenty-four (55.8\%) of the patients with complete injuries had accompanying trauma, while 15 (3I.2\%) of the patients with incomplete injuries had accompanying trauma. Table 4 shows the comparison of the patients with complete and incomplete injuries by accompanying trauma.

Forty-one of the patients (95\%) with complete injuries and 39 of the patients $(81 \%)$ with incomplete injuries were admitted to the Emergency Department within the first eight hours, while two patients with complete injuries and nine patients with incomplete injuries admitted to the Emergency Department within 8-12 hours. Eighty (87.9\%) of the patients involved in our study received steroid treatment. Forty-one (95\%) of the patients with complete injuries received steroid treatment, while $39(81 \%)$ of the patients with incomplete injuries received steroid treatment.

Sixty-three $(69.2 \%)$ of the patients received both medical and

Table 3. Comparison of the patients with complete and incomplete injuries by lesion sites

\begin{tabular}{|c|c|c|c|c|c|}
\hline & \multicolumn{2}{|c|}{ Complete $(n=43)$} & \multicolumn{2}{|c|}{ Incomplete $(n=48)$} & \multirow[t]{2}{*}{$\mathbf{p}$} \\
\hline & $\mathbf{n}$ & $\%$ & $\mathbf{n}$ & $\%$ & \\
\hline Cervical & 19 & 44.2 & 24 & 50.0 & $p>0.05$ \\
\hline Thoracic & 15 & 34.8 & 6 & 12.5 & $\mathrm{p}=0.010^{*}$ \\
\hline Lumbar & 9 & 21.0 & 18 & 37.5 & $p>0.05$ \\
\hline
\end{tabular}

Table 4. Comparison of the patients with complete and incomplete injuries by accompanying trauma

\begin{tabular}{|c|c|c|c|c|c|}
\hline & \multicolumn{2}{|c|}{ Complete $(n=43)$} & \multicolumn{2}{|c|}{ Incomplete $(n=48)$} & \multirow[t]{2}{*}{$\mathbf{p}$} \\
\hline & $\mathbf{n}$ & $\%$ & $\mathbf{n}$ & $\%$ & \\
\hline Head trauma & 4 & 9.3 & 3 & 6.3 & $p>0.05$ \\
\hline Thoracic trauma & 7 & 16.3 & 4 & 8.3 & $p>0.05$ \\
\hline Abdominal trauma & - & - & 4 & 8.3 & $\mathrm{p}=0.037^{*}$ \\
\hline Pelvic trauma & 2 & 4.7 & - & - & $p>0.05$ \\
\hline Extremity trauma & 1 & 2.3 & 2 & 4.2 & $p>0.05$ \\
\hline Multiple trauma & 10 & 23.3 & 2 & 4.2 & $\mathrm{p}=0.007^{*}$ \\
\hline No additional trauma & 19 & 44.2 & 33 & 68.8 & $\mathrm{p}=0.015^{*}$ \\
\hline
\end{tabular}

$*_{\mathrm{p}}<0.05$ significance level. 
Table 5. Complication and mortality rates of the patients with complete and incomplete injuries

\begin{tabular}{|c|c|c|c|c|c|}
\hline & \multicolumn{2}{|c|}{ Complete $(n=43)$} & \multicolumn{2}{|c|}{ Incomplete $(n=48)$} & \multirow[t]{2}{*}{$\mathbf{p}$} \\
\hline & $\mathbf{n}$ & $\%$ & $\mathbf{n}$ & $\%$ & \\
\hline Surgical site infection & 2 & 4.7 & 2 & 4.2 & $p>0.05$ \\
\hline Urinary tract infection & 5 & 11.6 & 5 & 10.4 & $p>0.05$ \\
\hline Pneumonia & 3 & 7 & - & - & $p>0.05$ \\
\hline GI hemorrhage & 2 & 4.7 & - & - & $p>0.05$ \\
\hline Bleeding (except GI) & II & 25.6 & 7 & 14.6 & $p>0.05$ \\
\hline Respiratory failure & 12 & 27.9 & 3 & 6.3 & $\mathrm{p}=0.005^{*}$ \\
\hline Total complication & 35 & 81.5 & 17 & 35.5 & $\mathrm{p}=0.000 \mathrm{I}^{*}$ \\
\hline Mortality & 16 & 37.2 & 3 & 6.3 & $\mathrm{p}=0.000 \mathrm{I}^{*}$ \\
\hline
\end{tabular}

surgical treatment, while 28 (30.8\%) received only medical treatment. Twelve (27.9\%) of the patients with complete injuries received only medical treatment, while 3 I $(72.1 \%)$ received both medical and surgical treatment. Sixteen (33.3\%) of the patients with incomplete injuries received only medical treatment, while $33(66.7 \%)$ received both medical and surgical treatment. No significant difference was found in the type of treatment between the patients with complete and incomplete injuries $(p>0.05)$.

Fifty-two (57.1\%) of the patients developed several complications, while 39 (42.9\%) developed no complications (Table 5).

In our study, 19 patients died; $37.2 \%(n=16)$ of them were in the complete injury group and $6.3 \%(n=3)$ were in the incomplete injury group $(p<0.05)$.

\section{DISCUSSION}

The frequency of spinal cord injuries in patients admitted to Emergency Departments due to spinal trauma is not clearly known. Nawar et al. could not report any rate of spinal injuries because the spinal injuries did not meet standards of reliability or precision. In the same study, all spinal disorders accounted for $2.5 \%$ of the visits to hospital Emergency Departments. They reported that the frequency of vertebral column injuries accounted for $4.8 \%$ of all trauma patients. ${ }^{[8]}$ In our study, we found a similar frequency of vertebral column injuries in all traumas. However, we could not draw any comparisons with spinal cord injuries due to the insufficient literature data.

Studies on spinal cord injuries take the ASIA classification as a guide and classify spinal cord injuries as complete (ASIAA) and incomplete (ASIA-B, C, D) according to this guide. $[3,4]$ The literature suggests that the complete injury rate is $45 \%$, while the incomplete injury rate is $55 \% .^{[2]}$ Our data of complete and incomplete injuries in our study was consistent with the literature.
We determined ASIA-IMSOP Impairment Scale grades of the patients during discharge and investigated any clinical recovery or deterioration. Nearly one in ten patients with a complete injury (Grade A) during admission improved to incomplete injury. Four percent of the incomplete injuries progressed to complete. Peker et al. ${ }^{[9]}$ reported that $23 \%$ of the spinal injuries classified as Grade $A$ according to the clinical findings during admission improved to incomplete. Peker et al. had twice as many recovered patients when compared with our study. We attributed this result to the fact that the number of patients in their study was lower, and the rate of the injuries that improved to incomplete was higher.

It is known that spinal cord injuries occur more frequently in young people, that the male/female ratio is $4 / \mathrm{I}$, and that motor vehicle accidents are the most common cause of spinal injuries. ${ }^{[2]}$ According to the data in our country, the male/ female ratio is $2.5 / 1$, and the rate of motor vehicle accidents is $48.8 \%{ }^{\left[{ }^{10}\right]}$ The male/female ratio was lower in our study when compared with the literature because the numbers of falls from height (from a tree) were higher in our study, and these falls mainly occurred in women. A study conducted in the southeastern Anatolia region reported that the male/female ratio was $5.8 / 1$, and the most common cause of spinal injuries was fall from height (37.5\%). ${ }^{\left[{ }^{11}\right]}$ In our study, a great majority of the patients were men and under 45 years of age, which was consistent with the literature.

Etiological factors of spinal cord injuries vary in different geographical regions, and the most common causes are motor vehicle accidents, violence and falls from height. ${ }^{[2,10]}$ Hagen et al. ${ }^{[8]}$ reported that common causes of spinal cord injuries were falls and motor vehicle accidents. A study conducted in our region reported that etiological factors in spinal cord injuries were falls from height, traffic accidents and diving into water, respectively. ${ }^{[12]}$ The most common etiological factor in our study was falls from height $(50.5 \%)$. This result derived from our study was consistent with the study conducted in our region by Gündüz et al. ${ }^{[2]}$ While spinal cord injuries due 
to motor vehicle accidents are more common in the United States or Europe, spinal cord injuries due to falls from height are more common in developing countries. ${ }^{[2,10]}$ Thus, it is true to say that there are inter-country and intra-country regional differences.

The literature reports that spinal cord injuries generally occur on the weekends or during holidays and the summer. ${ }^{[2]}$ A great majority of the patients in our study suffered spinal trauma in the summer.

Symptoms of spinal cord injuries are variable, and patients generally report pain, numbness-tingling, muscle weakness, urinary-fecal incontinence, respiratory distress, erythema, and temperature increase. ${ }^{[13]}$ The most common complaint of the patients in our study was numbness-tingling, followed by muscle weakness and pain, respectively. Most of the patients reported more than one complaint, and this was a little higher in the complete injury group.

A great majority of the patients with complete injuries suffered paraplegia, while a few suffered quadriplegia. The incidences of paraparesis and quadriparesis in the complete and incomplete injured patients were comparable. Önder et al. ${ }^{[14]}$ studied 65 patients, and reported that $6(9.2 \%)$ of the patients suffered paraparesis, $4(6.2 \%)$ suffered paraplegia, 13 (20\%) suffered quadriparesis, 21 (32.3\%) suffered quadriplegia, and $7(10.8 \%)$ suffered either hyposthenia or anesthesia, while 14 (2I.5\%) had no neurological deficit. Gündüz et al. ${ }^{[12]}$ reported that $4.6 \%$ of the patients suffered paraparesis, $16.2 \%$ suffered paraplegia, and $11.6 \%$ suffered quadriplegia, while 29 patients $(67.4 \%)$ had no neurological deficit. This result is likely to be attributed to the fact that all patients involved in our study had neurological deficit associated with the spinal trauma during admission, one of these reference studies included only patients with lower cervical injuries, the number of patients was lower, and the study also involved patients with no neurological deficit. Moreover, neither of these studies involved comparing or grouping the complete and incomplete injuries.

In their study involving 238 patients, Hagen et al. ${ }^{[8]}$ reported that the distribution according to the part of the vertebral column affected was cervical vertebrae (50\%), thoracic vertebrae (33\%), and lumbar vertebrae (17\%), respectively. In their study involving 43 patients, Gündüz et al. ${ }^{[2]}$ reported that cervical injuries were the most common. In our study, almost half of the patients with complete and incomplete injuries had cervical lesion.

Injury risk in the movable segments of the spinal column is very high. In their study involving 126 skiers with spinal cord injuries, Prall et al. ${ }^{\left[{ }^{[]}\right.}$reported that vertebral fractures resulting in spinal cord injuries occurred most commonly in $\mathrm{C6}$, TI 2 and LI. In our study, the most commonly fractured levels in the patients with cervical lesions were C5-6.
The thoracolumbar region is an anatomical and functional transition between the thoracic and lumbar parts as well as the most movable part of the spine. ${ }^{[13]}$ Therefore, TI2 is defined as the transition vertebra. The thoracolumbar spine is the region most exposed to trauma, and almost $60 \%$ of all vertebral body fractures occur between the TI 2 and $L 2$ vertebrae. ${ }^{[13]}$ In our study, almost one-third of the patients with complete and incomplete injuries had thoracolumbar fractures. The most common fractures in patients with complete and incomplete injuries who had thoracolumbar lesions were at LI and TI2. In our study, the most common mechanisms of trauma in the patients with thoracic trauma were falls from height and traffic accidents, and their incidences were equal. The most common etiological factor in thoracolumbar injuries was fall from height.

In their study, Armagan et al. ${ }^{[15]}$ reported that $26 \%$ of the patients had lumbar spine injuries. We determined that $30.7 \%$ of the patients involved in our study had lumbar spine injuries. Armagan et al. ${ }^{[5]}$ reported that traffic accidents were the etiological factor in half of the lumbar spine injuries, while falls from height were responsible in the other half. In our study, the most common mechanism of trauma in the patients with lumbar spine injuries was fall from height, followed by traffic accidents.

It is reported that spinal cord injuries are generally accompanied by head, thoracic or abdominal trauma. ${ }^{[2]}$ Almost half of the patients involved in our study had accompanying trauma. The incidence of multiple traumas in the patients with complete injuries was higher than in the incomplete injury group. Almost two-thirds of the patients with incomplete injuries had no accompanying trauma.

Methylprednisolone is suggested to be beneficial for spinal cord injuries because it is a radical scavenger, acts to prevent lipid peroxidation and has neuroprotective effects. ${ }^{[6]}$ Methylprednisolone infusion improves motor and sensory recovery in complete and incomplete spinal cord injuries. However, this expected positive result is based on using the steroid at the proper time and proper dose. ${ }^{[2]}$ A great majority of the patients in our study received steroid treatment. In our study, three patients who were first assessed as having complete injuries according to the clinical examination during admission and who later showed recovery in their ASIA grades received surgical treatment as well as steroid treatment. All of 10 patients who were first assessed as having incomplete injuries according to the clinical examination during admission and later showed recovery in their ASIA grades received surgical treatment as well as steroid treatment.

Armagan et al. ${ }^{[15]}$ reported that half of the hospitalized patients had neurological deficit, $78.9 \%$ of the patients with neurological deficit received surgical treatment while approximately $20 \%$ were treated through conservative care, and $29.4 \%$ of the patients with no neurological deficit received 
surgical treatment for stabilization. The authors reported that $55.5 \%$ of the patients received both medical and surgical treatment, while $44.5 \%$ received only medical treatment. ${ }^{[15]}$ In our study, almost one-third of the patients received only medical treatment, while two-thirds received both medical and surgical treatment.

Spinal cord injury recovery is inversely proportional to the trauma severity. The probability of locomotor function recovery after complete spinal cord injuries is around 1\%, while functional neurological recovery occurs in many patients with incomplete injuries. ${ }^{[7]}$ The factors affecting the recovery in patients with traumatic spinal cord injuries were reported as the initial level of injury, initial muscle strength, and patient age. ${ }^{[9,16]}$ Peker et al. ${ }^{[9]}$ reported that the mean age of the patients (being age over 30 ) and injuries with ASIA Grade A were the factors affecting recovery. Armagan et al. ${ }^{[15]}$ reported that almost half of the hospitalized patients had neurological deficit, and $21 \%$ of them were fully recovered while $58 \%$ were partially recovered. $14.2 \%$ of the patients in our study had functional recovery according to the ASIA-IMSOP Impairment Scale. Functional recovery occurred in $20.8 \%$ of the patients with incomplete injuries and in $7 \%$ of the patients with complete injuries. The patients first assessed as having complete injuries made little recovery.

Complications of spinal cord injuries are divided into two groups as acute and chronic. It was reported that the mortality and morbidity rates of acute complications were higher than those of chronic complications. ${ }^{[13]}$ Patients with spinal trauma developed complications associated with high-dose steroid treatment such as pneumonia, sepsis, injury infection, thromboembolism, gastrointestinal hemorrhage, and delayed recovery. ${ }^{[2]}$ Several respiratory problems may manifest themselves during the acute phase. It was reported that pulmonary complications of the patients with cervical spine injuries during the acute phase played a more crucial role than the level of injury in determining the hospitalization period. ${ }^{[17]}$ Complication rates in the patients with complete injuries are higher than in those with incomplete injuries. The morbidity and mortality rates based on complications were higher in the patients with complete injuries. ${ }^{[2,13]}$ In their study involving 27 patients, Peker et al. ${ }^{[9]}$ reported that the most common complication was urinary tract infection (8I\%), followed by pressure ulcers, urolithiasis, heterotopic ossification, pneumonia, and autonomic dysreflexia. Campos ${ }^{[18]}$ reported that pressure ulcers and urinary problems occurred most commonly. In their study, Balcı et al. ${ }^{[19]}$ reported that urinary tract infections and pressure ulcers were common complications. We determined that the most common complications that occurred in the patients involved in our study were hemorrhage (except for gastrointestinal hemorrhage), respiratory failure and urinary tract infection. Both the incidence of complications and the mortality rates were higher in the complete injury group.
According to the literature data, the mortality rates in the patients with spinal cord injuries vary between $4.4 \%$ and $16.7 \%$. ${ }^{[13]}$ However, it is reported that the rates in complete and incomplete injuries are different, and the morbidity and mortality rates in complete injuries are higher. ${ }^{[2]}$ Burney et al. ${ }^{[20]}$ reported that the hospital mortality rate of the patients with spinal cord injuries was 17\%. In their study involving 43 patients, Gündüz et al. ${ }^{[12]}$ reported that the in-hospital mortality rate was $6.9 \%$. Almost one-fifth of the patients involved in our study died, which was consistent with the literature. However, the mortality rate in our study was higher than in the other study conducted in our region. We attribute this result to the fact that all patients involved in our study had spinal cord injuries, while the other study conducted in our region involved the patients with spine and/or spinal cord injuries. A great majority of the deceased patients were male. More than half of the deceased patients had no accompanying trauma; however, a great majority of the patients with additional trauma had multiple traumas. The most common cause of death was respiratory failure. Most of the patients who died from respiratory failure had isolated cervical spine injuries.

In conclusion, our study presents data on the frequency of acute spinal trauma in emergency admission, its clinical picture, emergency care, follow-up, and prognosis. The results of our study show the significance of the Emergency Department approach (early diagnosis and true treatment) in acute spinal trauma cases. An emergency physician can decrease the incidence of unfavorable clinical results through both primary care and by taking necessary measures against possible complications.

Conflict of interest: None declared.

\section{REFERENCES}

1. Prall JA, Winston KR, Brennan R. Spine and spinal cord injuries in downhill skiers. J Trauma 1995;39:1115-8.

2. Baron BJ, McSherry KJ, Larson JL Jr, Scalea TM. Spinal cord injuries. In: Tintinalli JE, Kelen GD, Stapczynski JS, editors. Emergency medicine. A comprehensive study guide. 7th ed. New York: McGraw-Hill; 2011. p. 1709-30.

3. Maynard FM Jr, Bracken MB, Creasey G, Ditunno JF Jr, Donovan WH, Ducker TB, et al. International Standards for Neurological and Functional Classification of Spinal Cord Injury. American Spinal Injury Association. Spinal Cord 1997;35:266-74.

4. Sütbeyaz ST, Cay HF, Sezer N, Köseoglu F, Albayrak N. Demographic characteristics and complications of traumatic and nontraumatic spinal cord injured patients: A retrospective study. J PMR Sci 2006;9:6-10.

5. Hurlbert RJ. Methylprednisolone for acute spinal cord injury: an inappropriate standard of care. J Neurosurg 2000;93:1-7.

6. Topsakal C, Erol FS, Ozveren MF, Yilmaz N, Ilhan N. Effects of methylprednisolone and dextromethorphan on lipid peroxidation in an experimental model of spinal cord injury. Neurosurg Rev 2002;25:258-66.

7. Tator $\mathrm{CH}$. Strategies for recovery and regeneration after brain and spinal cord injury. Inj Prev 2002;8:33-6.

8. Hagen EM, Aarli JA, Grønning M. Patients with traumatic spinal cord 
injuries at the department of neurology, Haukeland Hospital 1952-99. [Article in Norwegian] Tidsskr Nor Laegeforen 2001;121:3273-5. [Abstract]

9. Peker O, Senocak O, Akalın E, Bircan C, Oncel S. Clinical characteristics of traumatic spinal cord injury patients and results of rehabilitation. The Journal of Turkish Spinal Surgery 2000;11:34-7.

10. Dryden DM, Saunders LD, Rowe BH, May LA, Yiannakoulias N, Svenson LW, et al. The epidemiology of traumatic spinal cord injury in Alberta, Canada. Can J Neurol Sci 2003;30:113-21.

11. Karacan I, Koyuncu H, Pekel O, Sümbüloglu G, Kirnap M, Dursun H, et al. Traumatic spinal cord injuries in Turkey: a nation-wide epidemiological study. Spinal Cord 2000;38:697-701.

12. Gündüz A, Narc1 H, Türedi S, Yandı M. Retrospective evaluation of spinal cord injury victims presented to the emergency department. Tr J Emerg Med 2005;5:28-31.

13. Kiriş T, Görgülü A. Omurilik travmaları. In: Ertekin C, Taviloğlu K, Güloğlu R, Kurtoğlu M, editors. Travma. 1 th ed. İstanbul: İstanbul Medikal Yayıncilık; 2005. p. 805-18.

14. Önder A, Kadioglu HH, Barlas E, Aydın İH. The prognosis of lower cervical spinal injury associated with multiple system trauma. Türk
Nöroşirürji Dergisi 1994;4:63-6.

15. Armagan E, Al G, Erdem M, Ozguc H, Tokyay R. An epidemiological and prognostic evaluation in patients with vertebral and/or spinal injuries who were admitted to first aid and emergency room at medical school of uludağ university. Ulus Travma Acil Cerr Derg 2000;6:110-3.

16. Kirshblum SC, O'Connor KC. Levels of spinal cord injury and predictors of neurologic recovery. Phys Med Rehabil Clin N Am 2000;11:1-27.

17. Winslow C, Bode RK, Felton D, Chen D, Meyer PR Jr. Impact of respiratory complications on length of stay and hospital costs in acute cervical spine injury. Chest 2002;121:1548-54.

18. da Paz AC, Beraldo PS, Almeida MC, Neves EG, Alves CM, Khan P. Traumatic injury to the spinal cord. Prevalence in Brazilian hospitals. Paraplegia 1992;30:636-40.

19. Balc1 N, Sepici V, Sever A. Evaluation of the results of rehabilitation of our spinal cord injured patients. Romatoloji ve Tibbi Rehabilitasyon Dergisi 1993;4:96-100.

20. Burney RE, Maio RF, Maynard F, Karunas R. Incidence, characteristics, and outcome of spinal cord injury at trauma centers in North America. Arch Surg 1993;128:596-9.

\section{KLINIIK ÇALIŞMA - ÖZET}

\section{Acil serviste üç yıllık deneyim: Spinal travmalı hastalara acil servis yaklaşımı ve prognozları Dr. Hızır Ufuk Akdemir, ${ }^{1}$ Dr. Dursun Aygün, ${ }^{2}$ Dr. Celal Katı, ${ }^{1}$ Dr. Mehmet Altuntaş, ${ }^{1}$ Dr. Cengiz Çokluk ${ }^{3}$}

1Ondokuz Mayıs Üniversitesi Tıp Fakültesi, Acil Tıp Anabilim Dalı, Samsun
${ }^{2}$ Ondokuz Mayıs Üniversitesi Tıp Fakültesi, Nöroloji Anabilim Dalı, Samsun
${ }^{3}$ Ondokuz Mayıs Üniversitesi Tıp Fakültesi, Nöroşirürji Anabilim Dalı, Samsun

AMAÇ: Spinal kord yaralanmaları gelişen nörolojik problemler nedeni ile oldukça ciddi maddi ve/veya manevi kayıplara neden olmaktadır. Bu çalışmanın amacı yüksek morbidite ve mortalite oranları nedeni ile ciddi klinik sonuçlara yol açan, ancak ülkemize ait sağlıklı verilerin az olduğu spinal yaralanmaların klinik şiddet ve prognoz açısından değerlendirilmesidir.

GEREÇ VE YÖNTEM: Bu geriye dönük çalışma, fakültemiz etik kurulundan izin alındıktan sonra Acil servisimize üç yıl içinde başvuran I 8 yaş ve üzerindeki spinal travmalı 9। hasta (59 erkek, 32 kadın) üzerinde gerçekleştirildi. Hastalar demografik özellikler, klinik şiddet, gelişen komplikasyonlar ve mortalite açısından değerlendirildi.

BULGULAR: Hastaların 43'ü komplet, 48'i ise inkomplet yaralanmalı idi. Hastaların 46'sı yüksekten düşme, 35'i trafik kazası ve I0'u diğer nedenlerden dolayı spinal yaralanmaya maruz kalmıştı. Hastaların 52'sinde çeşitli komplikasyonlar görülürken 39'unda herhangi bir komplikasyon gelişmediği saptandı. Çalışma grubumuzda yer alan 91 hastanın 19'unun öldüğü 72'sinin ise hastaneden taburcu olduğu saptandı.

TARTIŞMA: Spinal kord yaralanmaları genellikle kötü klinik sonuçlara yol açmaktadır. Bu nedenle acil servisteki uygun yaklaşımın (erken tanı ve doğru tedavi) önemi oldukça yüksektir. Bu hasta grubunda hem primer bakım hem de komplikasyonların önlenmesi bakımından gerekli önlemlerin alınması klinik sonuçları olumlu yönde etkileyecektir.

Key words: Klinik şiddet; komplikasyon; prognoz; spinal travma.

Ulus Travma Acil Cerr Derg 2013;19(5):44I-448 doi: 10.5505/tjtes.2013.21456 